\title{
Community-based ecotourism project in communities adjacent to the Addo Elephant National Park: Will households pay for it?
}

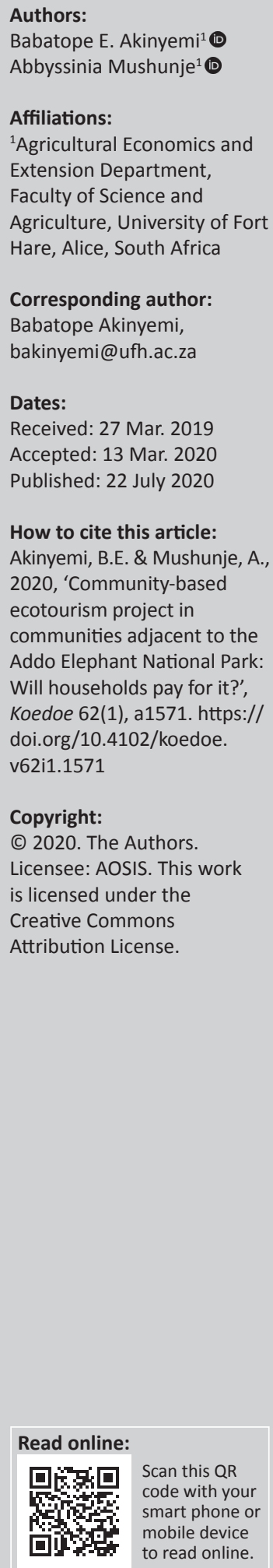

\begin{abstract}
Management of protected areas (PAs) that includes previously excluded households is gaining approval from both households living in communities adjacent to PAs and PA managers globally. This article examined households willingness to pay (WTP) for community-based ecotourism (CBE) project in adjacent communities to the Addo Elephant National Park (AENP). The study adopted two-stage sampling procedure to interview 198 respondents using double-bounded contingent valuation (CV) questionnaire administered through face-to-face interviews in five communities adjacent to the AENP. Quantitative data analysis was performed with descriptive statistics, pairwise correlation and seemingly unrelated bivariate probit. Findings reveal a strong association between respondent's support for CBE implementation and WTP. The null hypothesis that WTP is independent of the first bid price is strongly rejected. It was observed that first- and second-bid prices, and seven other variables determined WTP. Lastly, households are willing to pay between R121.00 and R125.00 monthly for a period of 3 years to support development of CBE initiative in their communities.

Conservation implications: This study established that households in communities adjacent to the AENP are in support of the establishment of CBE projects as long as they will be beneficial to them and their communities. This support is demonstrated by households' willingness to pay for the implementation of community-based projects. Hence, we concluded that the implementation of a CBE project can offer a market for craft-making, village accommodation and village tours that can showcase adjacent communities to visitors and thus assist the park management in strengthening the existing relationship between the park and communities.
\end{abstract}

Keywords: Addo elephant; bivariate probit; contingent valuation; community-based ecotourism; protected areas.

\section{Introduction}

South Africa's approach to the conservation of nature was a colonialist method, which was built on the idea that households living in communities adjacent to the protected areas (PAs) should be excluded to ensure optimum protection of plants, animals and the environment (Paterson 2007). However, this exclusionary approach to conservation is gradually giving way to a more inclusive approach to conservation, whereby communities surrounding PAs actively participate in both conservation and the sustainable use of the resources in Pas, which is a hallmark of the modern conservation model (Algotsson 2006; Balint 2007; Fabricius, Koch \& Magome 2001; Pelser, Redelinghuys \& Velelo 2013). The inclusion of local communities in conservation is important when viewed from the perspective of the effective environmental governance (EG), whereas, their exclusion often makes enforcement of conservation policies extremely difficult (Aswani \& Weiant 2004).

To formally integrate households with conservation efforts in South Africa, the South African National Parks (SANParks), which is the largest conservation and ecotourism provider within the country, established a Social Ecology Unit (SANParks 2011). This unit served as the precursor of the Households and Conservation Directorate in 2003 aimed at bringing about a households-parks interface by inculcating a culture of stewardship of the environment and raising awareness about conservation issues amongst local households (SANParks 2011). The legal framework of the households and parks support the preservation of the integrity of the ecosystems, whilst simultaneously acknowledging the vital role played by humans in the conservation of nature. Moreover, a draft policy on buffer zones for national parks was published 
in $2010^{1}$ to encourage sustainable development compatible with conservation values of the surrounding national park, and to help adjacent and affected communities obtain suitable and sustainable benefits. To fully harness these benefits, namely, promotion of conservation economy, ecotourism and its supporting structure, services and sustainability through a planned harvesting of biological resources have been suggested. ${ }^{2}$

\section{Ecotourism concept}

Ecotourism is a component of sustainable tourism that has been receiving growing attention for over three decades because of the environmental benefits that are intertwined with the well-being of local households. Although there is no universally accepted definition of ecotourism, the first definition given by Ceballos-Lascurain in 1987 defines ecotourism as 'travelling to relatively undisturbed or uncontaminated natural areas with the specific objective of studying, admiring and enjoying the scenery and its wild plants and animals'. The International Ecotourism Society (TIES) (1990) further defined ecotourism as a '... responsible travel to natural areas which conserves the environment and sustains the well-being of local households'. Ecotourism has become one of the world's major economic sectors with the capability to play a significant role in sustainable development in areas where nature attracts tourists (Fennel 2002; Powell \& Ham 2008).

The business model of SANParks is anchored on three core pillars, namely: conservation, nature-based tourism and community, which are perfectly aligned with the core values of ecotourism. In line with these core values, Buckley (2001) recommended that ecotourism product owners like SANParks should have a 'best practice model' that can be used as a benchmark to evaluate environmental performance and help in planning new ecotourism products responsibly. It is very important that SANParks implement an ecotourism model to successfully develop and manage its ecotourism products. Rest assured that SANParks management operations are well aligned with the core values of ecotourism principles, it has been established that no concrete model of ecotourism is currently in place to clearly show how ecotourism should be developed and managed in South Africa (De Witt, Van der Merwe \& Saayman 2011).

\section{Willingness to pay concept}

The concept of willingness to pay (WTP) or reservation price can be defined as the maximum price a given consumer accepts to pay for a product or service (Marine 2009). This concept is often used to identify the number of individuals that are willing to pay a given price for a particular product or service. Ability to measure consumer WTP makes it possible to calculate the demand curve according to price and to determine the price that offers the optimum feasible

1.Draft Policy on Buffer Zones for National Parks.

2.Draft Policy on Buffer Zones for National Parks 48. margin. If prices can be tailored, knowledge of WTP could enable optimisation of both sales volumes and margins. Knowing the factors that drive WTP allows it to be raised and offers the opportunity of increasing sales volumes for a given price or, when possible, to customise prices.

Some studies have adopted the concept of WTP to examine households' readiness to contribute or pay for ecotourism in communities adjacent to PAs in developing countries. For instance, Ezebilo, Mattsson and Afolami (2010) estimated communities' willingness to contribute for an ecotourism improvement project and its determinants in the Okwangwo Division of the Cross River National Park, Nigeria. The study revealed that households were willing to contribute an average of about $1 \%$ of their mean annual income and that willingness to contribute was influenced by income, distance of respondents' residence to the park, post-high school education, occupation and membership of an environmental conservation group. Similarly, Kimengsi et al. (2019) examined the extent to which respondents' assets drive ecotourism choices in Cameroon. The study revealed a high preference for the production and sale of arts and craft items and the promotion of cultural heritage sites as key ecotourism choices. Moreover, women were found to participate more in conservation education, as opposed to culture-related activities such as arts and crafts. Also, access to education and training was observed to be inversely related to the promotion of cultural festivals in the study (Kimengsi et al. 2019).

Hence, this study elicited households' WTP for communitybased ecotourism (CBE) initiative in the five villages bordering the Addo Elephant National Park (AENP). The study adopted the double-bounded contingent valuation (DBCV) method to elicit information on households' WTP for CBE in their villages. The 'Materials and methods' and the 'Results and discussion' sections present detailed descriptions of the methodology used, and the results and discussion of the study, respectively.

\section{Materials and methods Description of the study area}

This study was conducted in five communities bordering the AENP in the Eastern Cape Province of South Africa. The park straddles the following local and district authority boundaries: Sundays River Local Municipality; Ndlambe Local Municipality; Ikwezi Local Municipality; Blue Crane Local Municipality; Nelson Mandela Metropolitan; and Cacadu District Municipality. Eight adjacent communities that share proximities to the park include Nomathamsanqa, Valencia, Paterson, Enon, Bersheba, Joe Slovo, Moses Mabida and Colchester.

Historical records showed that Khoekhoen (Khoi Khoi) households arrived and settled in the area now designated as AENP between 2000 and 1500 years ago, and many of them died during an outbreak of smallpox that hit the area in the 
early 1700s (South Africa Nature Reserves \& National Parks 2016). Almost around the same period, the nomadic Xhosa tribes also arrived in the region, and many of them settled down in the northern-most part of Wit River. Several clashes ensued between the already settled Khoi Khoi settlers and the newly arrived nomadic Xhosa (South Africa Nature Reserves \& National Parks 2016).

Over a century ago, the area was also a focal point of bitter conflicts between pastoralists of European and African origin. During the Anglo-Boer War, a Boer commando, led by General Jan Smuts, entered the Zuurberg Mountains in September 1901 (Reitz 1929). The following day, the commando being severely pressed for food, cooked and ate the fruit of a cycad Encephalartos longifolius. About 80 men were poisoned, and 20 were very ill, some becoming unconscious, but fortunately all survived. The sick men made a dramatic escape from the advancing British forces (Ferreira 1980; Reitz 1929).

Whilst the war lasted, hunters poached elephants and other game animals in the area unabatedly and eventually by the early 1900s, there were only a few small populations of elephants left (Ferreira 1980). A ruling passed in 1919 by Major PJ Pretorious ordering that all of the remaining elephants in the area were to be exterminated saw 114 of these animals shot in just over a year. By 1931, only 11 elephants remained, and a national park was proclaimed in an effort to protect these wild animals (South Africa Nature Reserves \& National Parks 2016). Since the proclamation of the national park, efforts have been made to minimise poaching and other human-wildlife conflicts in and around the PAs.

One such effort is the Mayibuye Ndlovu (meaning 'let the elephant return' in Xhosa) Community Forum, which was established in 1993 to resolve conflicts between the park and the adjacent Nomathamsaqa community (Kate 2006). In recent times, due recognition has been accorded in the form of concessions and ecotourism development opportunities in and around the park, along with associated opportunities to supply goods and services to these businesses (Kate 2006). This has resulted in the expansion of the community forum to become more representative of all the local communities and the formation of the Mayibuye Ndlovu Development Trust (MNDT). This trust is represented by the park, the local government, the Sunday River Valley Tourism Forum and the eight surrounding local communities (SANParks 2005).

\section{Conceptual framework and empirical strategy}

The empirical analysis of a respondent's WTP for CBE development in this study is based on the bivariate probit model. The bivariate normal density function is appealing to statisticians because it allows non-zero correlation, whilst the logistic distribution does not. In addition, constraining the parameters of the bivariate probit model yields other models such as the interval data model and the random effect probit model (Cameron \& Quiggin 1994). Econometrically, modelling the data generated by the DBCV relies on the formulation given by:

$W T P_{i j}=u_{i}+\varepsilon_{i j}$

where $W T P_{i j}$ represents the $j^{\text {th }}$ respondent's WTP and $i=1,2$, denoting the first and the second questions as the means for the first and second responses. As before, setting $u 1=X^{\prime} i j b$ allows the means to be dependent upon the characteristics of the respondent. Following Haab and McConnell (2002), the $j$ th contribution to the likelihood function is given as:

$$
\begin{aligned}
L_{j}(\mu / t)= & \operatorname{Pr}\left(\mu_{1}+\varepsilon_{1_{j}} \geq t_{1}, u_{2}+\varepsilon_{2_{j}}<t_{2}\right)^{Y N} \\
& * \operatorname{Pr}\left(\mu_{1}+\varepsilon_{1_{j}}>t_{1}, u_{2}+\varepsilon_{2_{j}} \geq t_{2}\right)^{Y Y} \\
& * \operatorname{Pr}\left(\mu_{1}+\varepsilon_{1_{j}}<t_{1}, u_{2}+\varepsilon_{2_{j}}<t_{2}\right)^{N N} \\
& * \operatorname{Pr}\left(\mu_{1}+\varepsilon_{1_{j}}<t_{1}, u_{2}+\varepsilon_{2_{j}} \geq t_{2}\right)^{N Y}
\end{aligned}
$$

where $\mathrm{YY}=1$ for a 'yes-yes' answer, 0 otherwise, $\mathrm{NY}=1$ for a 'no-yes' answer, 0 otherwise and so on. This is the bivariate discrete choice model. Assuming normally distributed error terms with mean zero and respective variances $\sigma_{1}$ and $\sigma_{2}$, then $\mathrm{WTP}_{1 j}$ and $\mathrm{WTP}_{2 j}$ have a bivariate normal distribution with means $\mu_{1}$ and $\mu_{2}$, variances $\sigma_{1}$ and $\sigma_{2}$ and correlation coefficient $\rho$. As a result, the $j$ th contribution to the bivariate probit in Equation 3 is the likelihood function for the bivariate probit:

$L_{j}(\mu / t)=\Phi_{\varepsilon_{1} \varepsilon_{1}}\left(d_{1 j}\left(\left(t_{1}-u_{1}\right) / \sigma_{1}\right),\left(d_{2 j}\left(\left(t_{2}-u_{2}\right) / \sigma_{2}\right), d_{1} d_{2} \rho\right), \quad\right.$ [Eqn 3]

where

$\Phi \varepsilon_{1} \varepsilon_{2}$ is the standardised bivariate normal distribution function with zero means; $y_{1 j}=1$ if the response to the first question is yes and 0 otherwise

$y_{2 j}=1$ if the response to the second question is yes and 0 otherwise

$d_{1 j}=2 y_{1 j}-1$ and $d_{2 j}=2 y_{2 j}-1$

$\rho=$ correlation coefficient

$\sigma=$ standard deviation.

Although the double-bounded question format may be potentially biased, its use may be justified because it leads to lower mean squares error (Alberini 1995). It may also yield more conservative WTP estimates (Banzhaf et al. 2004) by narrowing down the confidence interval around WTP measures. The mean and median WTP as given by Huang and Smith (1998) was estimated using Equation 4:

$\hat{\mu}=-\left(\hat{\alpha}+\bar{X} \hat{\beta}_{0}\right) / \hat{\beta}$

[Eqn 4]

where $\hat{\beta}_{0}$ is the coefficient on the bid amount. As shown in Cameron and James (1987), the coefficient on the bid amount is a point estimate of $1 / \sigma$. The dispersion parameter or standard deviation of WTP is thus estimated at:

$\hat{\sigma}=1 / \hat{\beta}$

[Eqn 5] 
Presented in Table 1 are the variables included in the bivariate probit model. It shows the variables, types of measures and their descriptions. Two categories of variables dealing with respondents' socio-economic characteristics and their knowledge of deforestation in the AENP, tourism and ecotourism are also presented.

\section{Description of data}

The contingent valuation survey was implemented amongst respondents selected from five villages (Enon, Bersheba, Moses Mabida, Nomathamsanqa and Valencia) adjacent to the AENP. The park ranks as the third-largest national park after the Kruger national Park and the Kgalagadi Transformation Park in South Africa. It is unique for being the most biologically diverse park in Africa (AENP 2015). In its present state, it represents five of South Africa's seven biomes, namely, the Nama Karoo, Fynbos, Forest, Thicket, Grassland and the Azonal Wetland (only lacking are the Succulent Karoo and Savannah) (Vlok, Euston-Brown \& Cowling 2003). The park is also the only park in South Africa with the big seven because of its coastal area.

The study employed a two-stage sampling technique to identify 198 households as presented in Table 2. In the first stage, the names of eight villages adjacent to the AENP were retrieved from SANParks with which authors signed a contractual agreement. From these eight villages, five villages adjacent to the PA were selected using simple random sampling, which is a probability sampling method. The second stage involved non-probability convenience sampling of households that are willing to participate in the study from the selected villages. The choice of the convenience sampling method was informed by non-availability of sampling frame from which random sample can be drawn for the study. Five enumerators from the five selected communities were recruited through the assistance of MNDT, and the enumerators were trained by the researcher on how to administer the questionnaire to the respondents in their local language to ensure a clear understanding of the study. The data were collected in March 2016.
The respondents were assured of their confidentiality, and their privacy was respected. Enumerators informed the respondents of the aim of the study and secured their consents before commencing the interviews. In all, a total of 210 copies of questionnaires were administered to households in communities adjacent to the PAs. Of all the copies of the questionnaire administered, 198 representing a $94 \%$ response rate, contained meaningful information for analysis. This sample size aligned with the findings of Heechan (2006), which confirmed that the statistical gain of the bivariate probit model is negligible for sample sizes ranging from 200 to 1000 . Moreover, similar studies (Ezebilo et al. 2010; Kimengsi et al. 2019) implemented in Nigeria and Cameroon used sample sizes ranging from 150 to 200 respondents. This study was ethically approved by the University of Fort Hare, with the ethic clearance certificate number (REC-270710-028-RA Level 01). The researcher assured the study respondents that the findings of the study will be shared with them through MNDT, and the research findings were shared with MNDT at the completion of the study in September 2016.

\section{Description of the hypothetical market}

Before posing the DBCV WTP questions to the respondents, description of the contingent good (CBE project) was established. It was explained to respondents that 'visitors to the AENP may be interested in participating in CBE projects'. These projects include: participating in craft-making market, using village accommodation and engaging in village tours that will take visitors to historic sites within their villages and

TABLE 2: Sampling procedure for households.

\begin{tabular}{lcc}
\hline Adjacent communities & $\begin{array}{c}\text { Copies of questionnaire } \\
\text { administered }\end{array}$ & $\begin{array}{c}\text { Copies of questionnaire } \\
\text { retrieved }\end{array}$ \\
\hline Bersheba & 40 & 40 \\
Enon & 40 & 36 \\
Moses Mabida & 45 & 42 \\
Nomathamsanqa & 45 & 40 \\
Valencia & 40 & 40 \\
\hline Total & $\mathbf{2 1 0}$ & $\mathbf{1 9 8}$ \\
\hline
\end{tabular}

TABLE 1: A priori expectations of the determinants of willingness to pay for community-based ecotourism.

\begin{tabular}{|c|c|c|}
\hline Variables & Types & Descriptions \\
\hline Bids $\mathrm{X}_{1}$ & Continuous & Hypothetical monthly payment suggested to the respondents in the survey \\
\hline Age $X_{2}$ & Discrete & Age of respondents in years at the time of the survey \\
\hline Male $\mathrm{X}_{3}$ & Dummy & 1 if male, 0 otherwise \\
\hline Education $\mathrm{X}_{4}$ & Discrete & Household head's years of formal education \\
\hline Married $\mathrm{X}_{5}$ & Dummy & 1 if married, 0 otherwise \\
\hline Dependency ratio $X_{6}$ & Continuous & Ratio of non-workers to workers in the households \\
\hline Log of income $\mathrm{X}_{7}$ & Continuous & Log of monthly income of respondents in South African rand \\
\hline Crop farming $\mathrm{X}_{8}$ & Dummy & 1 if the households are engaged in crop farming, 0 otherwise \\
\hline Distance $\mathrm{X}_{9}$ & Continuous & Distance of residence to nature reserve in kilometres \\
\hline Xhosa $X_{10}$ & Dummy & 1 if households is Xhosa, 0 otherwise \\
\hline Deforestation knowledge $X_{11}$ & Dummy & 1 if knowledgeable about deforestation, 0 otherwise \\
\hline Deforestation threat $\mathrm{X}_{12}$ & Dummy & 1 if considers deforestation as a threat to protected area, 0 otherwise \\
\hline Deforestation concerns $\mathrm{X}_{13}$ & Dummy & 1 if concerned about deforestation, 0 otherwise \\
\hline Contribution to environment $\mathrm{X}_{14}$ & Dummy & 1 if contributes money to environmental causes, 0 otherwise \\
\hline Ecotourism awareness $\mathrm{X}_{15}$ & Dummy & 1 if aware of ecotourism, 0 otherwise \\
\hline Involvement in tourism business $\mathrm{X}_{16}$ & Dummy & 1 if any households member is involved in tourism job, 0 otherwise \\
\hline Instrument usefulness $X_{17}$ & Dummy & 1 if the questionnaire was considered to contain useful information, 0 otherwise \\
\hline
\end{tabular}


also expose visitors to their cultural values. This project will provide alternative sources of livelihood, which may reduce exploitation of natural resources, thereby minimising the rate of deforestation. The respondents were informed that the establishment of $\mathrm{CBE}$ in their villages would require each household to contribute a monthly payment for the funding of the project for the next 3 years. This is important because evidence reveals that individuals respond differently when responding to hypothetical questions than when having to make real payment (List \& Gallet 2001). Because consumers usually dislike increase in prices (Jeanty 2006), payment methods like an increase in federal or provincial taxes and prices were not considered.

The elicitation method used in the households' survey is the double-bounded dichotomous choice (DB DC) format. The DB DC format questions ask the respondent whether they would vote 'yes' on a policy that would cost her household an initial amount in South African Rands. If the respondent says 'yes' (respectively, no), another WTP question was asked using a higher (respectively, lower) price. A common problem found in this survey design is starting point bias, as recognised by Herriges and Shrogren (1996). It has to do with the design of the bid vector and occurs when the initial bid introduced in the survey influences the respondent's level of WTP. According to Mitchell and Carson (1989), anchoring effect and yes-saying bias are two major sources of starting point bias. To deal with starting point bias in this study, contingent valuation method (CVM) questionnaire was designed with an optimal number and the distribution of bids to offer improved efficiency (Alberini 1995).

The questionnaire has three sections. The first section deals with the respondent's knowledge of deforestation and information relating to tourism and ecotourism activities in the AENP. The second section contains the valuation scenario, which attempts to provide as much information as possible about the hypothetical market. Guidelines suggested by Carson (2000) and the NOAA panel (Arrow et al. 1993) for valid contingent valuation analysis were followed as much as possible. The sets of bids used in the scenario were: $25,12,50 ; 40,20,80 ; 60,30,120$ and 100, 45, 200, where the first element of each set represents the first bid. The second element corresponds to the lower bid if the respondent answers 'no' to the first bid and the third element corresponds to the higher bid if the response to the first bid is a 'yes'. All bids are in South African Rands.

To establish the institutional setting in which the CBE project was to be implemented, a scenario was presented to respondents:

[W]hereby the South African National Parks (SANParks) was considering a community-based ecotourism project that will provide village accommodation, craft market and village tour that will expose visitors to the local culture of the households.

However, consistent with the previous work by Loureiro Gracia and Nayga (2006), the respondents were not explicitly told whether findings from this study would affect these considerations. Providing this information to the respondents could have affected their decisions, given the context in which the project is to be implemented. The last part of the questionnaire deals with the socio-economic characteristics of the respondents.

\section{Ethical consideration}

Ethical approval to conduct the study was obtained from the University of Fort Hare (UREC). (reference number MUS181SAKI01)

\section{Results and discussion}

The demographic characteristics of the respondents that participated in the study are presented in Table 3. On an average, respondents were willing to give R57.00 and R80.00 for the first and second bids presented to them. The mean age of the participants in the study is 40 years. This mean age is 11 years lower than the 51 years reported for the entire province in 2014 General Households Survey (Statistics South Africa 2014). This suggests that these respondents are in their economically active years. Majority of the participants are males, represented by $52 \%$ of the study population. An average household head in the study area attended school for 9 years, whilst 35\% are married. The dependency ratio of the households defined by the ratio of non-working household members to the working household members indicates that $78 \%$ have a dependency ratio that is greater than 1 . Seventyfive per cent of the respondents are of Xhosa descent, which is similar to the Census 2011 figure. It was reported that Xhosa constituted $77 \%$ of the population in the study area.

Furthermore, the mean distance of household's residence to the AENP is $17.57 \mathrm{~km}$. The fact that respondents live a mere $17 \mathrm{~km}$ away from the PA suggests that they may be familiar enough with the PA in order to value it. Studies have also

TABLE 3: Descriptive statistics of independent variables.

\begin{tabular}{lcccc}
\hline Variables & Mean & $\begin{array}{c}\text { Standard } \\
\text { deviation }\end{array}$ & Minimum & Maximum \\
\hline First Bid $\mathrm{X}_{1}$ & 57.77 & 28.11 & 25 & 100 \\
Second Bid $\mathrm{X}_{1}$ & 80.60 & 59.09 & 12 & 200 \\
${\text { Age } \mathrm{X}_{2}}$ & 40.18 & 12.20 & 22 & 87 \\
${\text { Male } \mathrm{X}_{3}}$ & 0.52 & 0.50 & 0 & 1 \\
Education $\mathrm{X}_{4}$ & 9.29 & 3.68 & 0 & 18 \\
Married $\mathrm{X}_{5}$ & 0.35 & 0.48 & 0 & 1 \\
Dependency ratio $\mathrm{X}_{6}$ & 0.78 & 0.78 & 0 & 6 \\
Income $\mathrm{X}_{7}$ & 2265.15 & 2920.00 & 0 & 15000 \\
Crop farming $\mathrm{X}_{8}$ & 0.24 & 0.43 & 0 & 1 \\
Distance $\mathrm{X}_{9}$ & 17.57 & 13.76 & 1 & 78 \\
Xhosa $\mathrm{X}_{10}$ & 0.75 & 0.42 & 0 & 1 \\
Deforestation knowledge $\mathrm{X}_{11}$ & 0.43 & 0.49 & 0 & 1 \\
Deforestation threat $\mathrm{X}_{12}$ & 0.54 & 0.49 & 0 & 1 \\
\hline Deforestation concerns $\mathrm{X}_{13}$ & 0.82 & 0.38 & 0 & 1 \\
Contribution to environment $\mathrm{X}_{14}$ & 0.15 & 0.35 & 0 & 1 \\
Ecotourism awareness $\mathrm{X}_{15}$ & 0.63 & 0.48 & 0 & 1 \\
\hline Involvement in tourism business $\mathrm{X}_{16}$ & 0.05 & 0.22 & 0 & 1 \\
\hline Instrument usefulness $\mathrm{X}_{17}$ & 0.68 & 0.46 & 0 & 1 \\
\hline & & & & \\
\hline
\end{tabular}


shown that the proximity to a resource, the more the WTP for it (Biadgilign et al. 2015). A monthly income of R2265.15 was reported as the mean monthly income in the study. This mean monthly income is comparatively lower than the average annual income of R6400.00 for the Eastern Cape Province, as reported in Statistics South Africa, 2012. However, we believe that this figure is commensurate with the level of education reported by the respondents in the study area. Regarding the six variables measuring respondents' knowledge of deforestation, deforestation to the AENP, concerns about deforestation, contribution to environmental cause, awareness of ecotourism and involvement in tourism-related business, $43 \%, 54 \%, 82 \%, 15 \%, 63 \%$ and 5\%, respectively, were affirmative to these questions. When asked about the usefulness of the information provided in the questionnaire for the respondents to make decisions, $68 \%$ affirmed that the questionnaire was useful.

To establish zero WTP amongst the study participants, they were first asked whether or not they would favour CBE if funding was made available from either government or nongovernmental organisations (NGOs). As indicated in Table 4, about $84 \%$ of the respondents indicated that they would favour the CBE project if money is made available by the government and/or NGOs. Amongst the respondents that support the project, about $73 \%$ were affirmative in their response to the first bid. Of the $15.6 \%$ that were against the CBE project, all responded negatively to the first WTP question. Correlation test results presented in Table 4 reject the null hypothesis that whether respondents would favour CBE development is independent of their responses to the first WTP question at $1 \%$ level of significance. It invariably implies that household's response to the first WTP question is strongly associated with either they are in favour or against the implementation of the CBE project.

Distribution of respondents' responses to the first bid and the results testing the null hypothesis that the responses are independent of the first -bid amount in Rand is presented in Table 5. The null hypothesis is strongly rejected at $1 \%$ level of significance. This means that respondents take into account the bid amounts when stating their WTP. The first three rows in Table 5 describe each bid level. The first row corresponds

TABLE 4: Association between community-based ecotourism support and the first bid payment.

\begin{tabular}{llccc}
\hline \multirow{2}{*}{$\begin{array}{l}\text { Community-based } \\
\text { ecotourism development }\end{array}$} & Statistics & \multicolumn{2}{c}{ Response to the first bid } & \multirow{2}{*}{ Total } \\
\cline { 3 - 4 } & & No & Yes & \\
\hline In favour of community- & Frequencies & 44 & 123 & 167 \\
$\begin{array}{l}\text { based ecotourism } \\
\text { development }\end{array}$ & Percentages & 26.35 & 73.65 & 100.00 \\
& Percentages & 58.67 & 100.00 & 84.34 \\
Against community-based & Frequencies & 31 & 0 & 31 \\
ecotourism development & Percentages & 100.00 & 0.00 & 100.00 \\
& Percentages & 41.33 & 0.00 & 15.66 \\
\hline Total & Frequencies & $\mathbf{7 5}$ & $\mathbf{1 2 3}$ & 198 \\
& Percentages & $\mathbf{3 7 . 8 8}$ & $\mathbf{6 2 . 1 2}$ & $\mathbf{1 0 0 . 0 0}$ \\
& Percentages & $\mathbf{1 0 0 . 0 0}$ & $\mathbf{1 0 0 . 0 0}$ & $\mathbf{1 0 0 . 0 0}$ \\
\hline
\end{tabular}

Pearson's chi ${ }^{2}(1)=60.2774, p$-value $=0.000$.

Likelihood ratio $\mathrm{chi}^{2}(1)=70.1293, p$-value $=0.000$.

Fisher's exact test, $p$-value $=0.000$

1 -sided Fisher's exact test, $p$-value $=0.000$. to the frequency of 'no' and 'yes' answers to the specified bid amount in Rand and to the total number of the respondents who were exposed to that bid amount. The second row represents the percentage of 'no' and 'yes' responses amongst those who were offered the bid amount. The third row indicates the percentage of respondents who indicated 'no' and 'yes' for that particular bid across all respondents that were offered the bid.

For bid R25.00, the first row indicates that 44 respondents were exposed to this bid, amongst which 17 rejected the bid price (i.e. No) and 27 accepted the bid price (i.e. Yes), whereas the second row implies that 17 represent $38.64 \%$ and 27 represent $61.36 \%$. The third row suggests that $22.22 \%$ of the respondents were offered the first bid of R25.00 and that amongst all respondents, $22.67 \%$ said 'no' and $21.95 \%$ said 'yes' to the first bid of R25.00. Theoretically, the third row indicates that the bids satisfy the monotonicity assumption, which implies that the percentage of the respondents who indicated 'no' should monotonically increase as the bid amount increases. As indicated in Table 5, both 'no' and 'yes' responses satisfy monotonicity, as suggested by upward and downward sloping Hicksian demand function.

The graphical representation of the monotonicity assumption is shown in Figure 1. It is anticipated that the likelihood of respondents saying 'yes' to the lowest bid should be close to 1 , and the likelihood of saying 'yes' to the highest bid should be close to 0 . In this study, $61 \%$ of the respondents indicated 'yes' to R25.00 the lowest first bid, and 48\% indicated 'no' to the highest first bid of R100.00.

The contingency table, which compares the first and second responses of the bids, is presented in Table 6 . It shows that amongst those who said 'no' to the first bid, $69.3 \%$ said 'no' and $30.4 \%$ said 'yes' to the second bid. Amongst those who answered affirmatively to the first bids, 19.5\% said 'no' and $80.4 \%$ said 'yes' to the second bid. Counterintuitively, 'dominant effect' phenomenon, whereby respondents who

TABLE 5: Response distribution for the first bids.

\begin{tabular}{llccc}
\hline \multirow{2}{*}{$\begin{array}{l}\text { First bid amount } \\
\text { (Rand) }\end{array}$} & Statistics & \multicolumn{2}{c}{ Response to the first bid } & Total \\
\cline { 2 - 4 } & & No & Yes & \\
\hline 25 & Frequencies & 17 & 27 & 44 \\
& Percentages & 38.64 & 61.36 & 100.00 \\
& Percentages & 22.67 & 21.95 & 22.22 \\
40 & Frequencies & 19 & 30 & 49 \\
& Percentages & 38.78 & 61.22 & 100.00 \\
& Percentages & 25.33 & 24.39 & 24.75 \\
60 & Frequencies & 14 & 39 & 53 \\
& Percentages & 26.42 & 73.58 & 100.00 \\
& Percentages & 18.67 & 31.71 & 26.77 \\
100 & Frequencies & 25 & 27 & 52 \\
& Percentages & 48.08 & 51.92 & 100.00 \\
& Percentages & 33.33 & 21.95 & 26.26 \\
\hline Total & Frequencies & $\mathbf{7 5}$ & $\mathbf{1 2 3}$ & 198 \\
& Percentages & $\mathbf{3 7 . 8 8}$ & $\mathbf{6 2 . 1 2}$ & $\mathbf{1 0 0 . 0 0}$ \\
& Percentages & $\mathbf{1 0 0 . 0 0}$ & $\mathbf{1 0 0 . 0 0}$ & $\mathbf{1 0 0 . 0 0}$ \\
\hline
\end{tabular}

Pearson $\mathrm{chi}^{2}(3)=5.2858, p$-value $=0.152$

Likelihood-ratio $\mathrm{chi}^{2}(3)=5.3812$, $p$-value $=0.146$. Fisher's exact $=p$-value $=0.151$. 


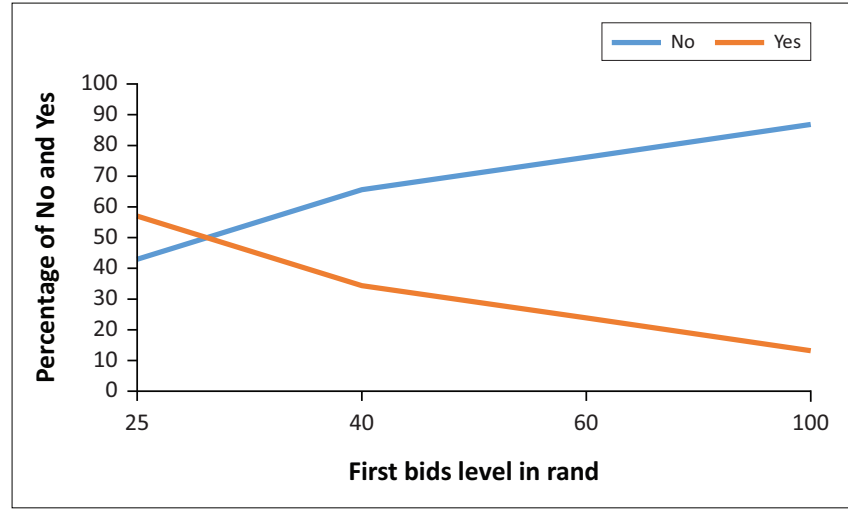

FIGURE 1: Percentage of 'no' and 'yes' to the first bid amounts.

initially said 'yes' persisted in saying yes and those who initially said 'no' are inclined to persist in saying 'no' was not satisfied for both 'no' and 'yes' responses in this study (Cameron \& Quiggin 1994). The test of the null hypothesis that the first and second responses are independent was implemented, and the results indicated that the null hypothesis should be rejected. This implies that the responses to the first and the second questions are correlated.

The results of the seemingly unrelated bivariate probit model showing the summary statistics of coefficients, standard errors and levels of significance for first and second responses are presented in Table 7. When implementing the model, we assumed that the same exogenous variables appear in both equations because there are no requirements that different variables should appear in the two equations (Green 2018). The conditional tetrachoric correlation $(\rho)$ of the error terms (Green 2018) capturing the correlation between the binary variables (responses to first and second bids) of 11.70 indicates that there is a correlation between the binary variables. Of all the 17 variables included in the bivariate probit model, the first bid: residents' distance to the AENP, Xhosa, deforestation concerns, ecotourism awareness and instrument usefulness are significant in the first equation. Whilst, that of second bid: being married, log of income, deforestation knowledge, deforestation concerns and instrument usefulness are significant in the second equation.

Respondents' WTP for CBE in communities adjacent to the AENP is strongly related to both first and second bid amounts. It also follows a priori negative sign as anticipated (Du Preez, Tessendorf \& Hosking 2010; Jeanty 2006). The negative signs indicate that as the bid amount offered to the household increases, their WTP for CBE decreases. The finding follows the popular axiom of demand theory, which states that the higher the price, the lower the quantity demanded. Although being married is not significant in the first equation, it significantly influences respondents' response to the follow-up WTP question. The positive coefficient of the married variable implies that respondents that are married are most likely to be willing to pay for the project than their counterparts who are single, divorced or widowed. Because marriage often comes with responsibility
TABLE 6: Test of independence between the first and the second responses.

\begin{tabular}{llccc}
\hline First responses & Statistics & \multicolumn{2}{c}{ Second responses } & Total \\
\cline { 3 - 4 } & & No & Yes & \\
\hline No & Frequencies & 52 & 23 & 75 \\
& Percentages & 69.33 & 30.47 & 100.00 \\
& Percentages & 68.42 & 18.85 & 37.88 \\
Yes & Frequencies & 24 & 99 & 123 \\
& Percentages & 19.51 & 80.49 & 100.00 \\
& Percentages & 31.58 & 81.15 & 62.12 \\
\hline Total & Frequencies & $\mathbf{7 6}$ & $\mathbf{1 2 2}$ & 198 \\
& Percentages & $\mathbf{3 8 . 3 8}$ & $\mathbf{6 1 . 6 2}$ & $\mathbf{1 0 0 . 0 0}$ \\
& Percentages & $\mathbf{1 0 0 . 0 0}$ & $\mathbf{1 0 0 . 0 0}$ & $\mathbf{1 0 0 . 0 0}$ \\
\hline
\end{tabular}

Pearson $\operatorname{chi}^{2}(1)=48.8974, p$-value $=0.000$.

Likelihood-ratio $\mathrm{chi}^{2}(1)=49.8230, p$-value $=0.000$.

Fisher's exact $=p$-value $=0.000$.

One-sided Fisher's exact $=p$-value $=0.000$.

TABLE 7: Seemingly unrelated bivariate probit regression results.

\begin{tabular}{|c|c|c|c|c|}
\hline \multirow[t]{2}{*}{ Variables } & \multicolumn{2}{|c|}{ Response to bid1 } & \multicolumn{2}{|c|}{ Response to bid2 } \\
\hline & Coefficients & $\begin{array}{l}\text { Standard } \\
\text { error }\end{array}$ & Coefficients & $\begin{array}{l}\text { Standard } \\
\text { error }\end{array}$ \\
\hline Bids $\mathrm{X}_{1}$ & $-0.0097 * * *$ & 0.0038 & $-0.0109 * * *$ & 0.0018 \\
\hline Age $X_{2}$ & -0.0027 & 0.0144 & -0.0074 & 0.0117 \\
\hline Male $X_{3}$ & 0.0018 & 0.3327 & 0.1046 & 0.2695 \\
\hline Education $\mathrm{X}_{4}$ & 0.0462 & 0.0415 & -0.0085 & 0.0330 \\
\hline Married $X_{5}$ & -0.0781 & 0.3516 & $0.5472 * *$ & 0.2848 \\
\hline Dependency ratio $X_{6}$ & -0.0699 & 0.2538 & -0.1090 & 0.1540 \\
\hline Log of income $X_{7}$ & 0.2454 & 0.1657 & $0.2745 * *$ & 0.1421 \\
\hline Crop farming $\mathrm{X}_{8}$ & 0.0948 & 0.3252 & 0.2916 & 0.2881 \\
\hline Distance $\mathrm{X}_{9}$ & $-0.0285 * *$ & 0.0124 & -0.0131 & 0.0090 \\
\hline Xhosa $X_{10}$ & $0.7193^{*}$ & 0.4219 & -0.3098 & 0.3468 \\
\hline $\begin{array}{l}\text { Deforestation } \\
\text { knowledge } \mathrm{X}_{11}\end{array}$ & 0.4666 & 0.3896 & $0.5926 *$ & 0.3370 \\
\hline Deforestation threat $\mathrm{X}_{12}$ & 0.3550 & 0.3906 & 0.4678 & 0.3159 \\
\hline Deforestation concerns $X_{13}$ & $0.8947 * *$ & 0.3804 & $0.5887^{*}$ & 0.3341 \\
\hline $\begin{array}{l}\text { Contribution to } \\
\text { environment } \mathrm{X}_{14}\end{array}$ & -0.1393 & 0.4653 & -0.0908 & 0.3419 \\
\hline Ecotourism awareness $X_{15}$ & $0.6444 *$ & 0.4000 & 0.0791 & 0.3278 \\
\hline $\begin{array}{l}\text { Involvement in tourism } \\
\text { business } X_{16}\end{array}$ & 0.1233 & 0.5848 & -0.2647 & 0.5225 \\
\hline Instrument usefulness $X_{17}$ & $1.5555 * * *$ & 0.3773 & $1.5720 * * *$ & 0.2936 \\
\hline Constant & $-3.5491 * * *$ & 1.4016 & $-2.2378 * *$ & 1.1096 \\
\hline
\end{tabular}

$N=154 ;$ Prob. $>\mathrm{Chi}^{2}=0.0000 ;$ LogL $=-107.22575 ;$ Wald $\mathrm{Chi}^{2}=100.87$.

$*, * *$ and $* * *$ significant at $10 \%, 5 \%$ and $1 \%$ levels.

in Africa, married respondents may see this project as a way of contributing to society.

In addition, the log of monthly household's income is significant with a positive sign as intuitively anticipated. This obviously means that respondents with a higher income are likely to pay for CBE than respondents with a lower income. This finding corroborated past studies that show that households' WTP is often contingent on the level of income of the households (Bonan, Lemay-Boucher \& Tenikue 2013; Hadker et al. 1997). The variable Distance is another important variable that may greatly influence WTP. It is strongly significant $(1 \%)$ with a negative sign as expected in the first equation but insignificant with a priori negative coefficient sign in the second equation. This result is particularly true of the study area, as previous studies revealed inter-community conflict relating to the location of developmental programmes in the past (Timmermans \& Naicker 2002). 
The Xhosa variable is significant at $10 \%$ with a positive sign coefficient estimate. This suggests that respondents who are of Xhosa descent are more likely to answer 'yes' to the WTP question than other tribes living in the study area. This finding may not be unconnected to the sense of ownership shared by the Xhosa on their rights to the natural resource stemming from the age-long history of the households (Timmermans \& Naicker 2002). Also, the traditional cultural circumcision of young male Xhosa in the forest may be connected to their WTP for the CBE, which will help in the conservation of forest resources around this PA. Similarly, it was observed that being deforestation concerned significantly influenced respondents' WTP for CBE when presented with both bid amounts, albeit at 5\% for the first equation and 10\% for the second equation. This finding aligns with Jeanty's (2006) study that individuals concerned about deforestation tend to express positive WTP. However, findings of the study contradict Akinyemi and Mushunje (2017) which found that respondents are concerned about deforestation are less willing to pay for CBE in Eastern Cape Wild Coast, South Africa.

Finally, it was observed that respondents' awareness of ecotourism at $10 \%$ significantly affects respondents' WTP for the first bid. Meanwhile, the coefficient on instrument usefulness variable is positive and strongly significant at $1 \%$ for both equations. As a result, respondents that find information in the questionnaire useful tend to be more willing to pay for the project than their counterparts who found it less informative. Both findings were intuitively anticipated a priori because it is only right to expect that the more the level of awareness of ecotourism and its benefits households have, the more their WTP. Similarly, if respondents clearly understand the hypothetical market described in the questionnaire and its environmental market value, they are probably more likely to be willing to pay than those who do not understand.

The distribution of the average WTP estimates, the lower and upper bound parameters from the DBCV, achieved significance level, confidence intervals using Krinsky and Robb procedures are presented in Table 8 . The confidence intervals reported in this study were estimated with 50000 draws as recommended by Krinsky and Robb (1986) and Park, Loomis and Creel (1991). In computing mean/median WTP, mean income from survey data is used. In the first instance, it was observed that the estimated mean/median WTP increased from R121.78 to R125.84 when the second question was introduced. This is a counterintuitive result of

TABLE 8: Mean/median willingness to pay the amount.

\begin{tabular}{lcc}
\hline Statistics & DB WTP 1 & DB WTP 2 \\
\hline Mean/median WTP & 121.78 & 125.84 \\
Lower bound & 82.28 & 104.32 \\
Upper bound & 319.86 & 155.10 \\
ASL & 0.0053 & 0.0000 \\
Krinsky-Robb Cl & 1.95 & 0.40 \\
\hline
\end{tabular}

$\mathrm{DB}$, double bound; ASL, achieved significance level; WTP, willingness to pay; $\mathrm{Cl}$, confidence interval. the double bounded modelling. The variation in the binary responses conveys information about the error in each equation because the bid amounts vary across individuals. The results of this study imply that the actual 'willingness to pay' of the respondents in communities adjacent to the PAs in the study area may be lower than the amount estimated by the DBCV. Therefore, further study may be required to empirically clarify this.

\section{Conclusion}

The aim of this study was to measure household's WTP for the development of $\mathrm{CBE}$ in communities adjacent to the AENP, South Africa. In addition, we measured the association between households' support for CBE implementation and their WTP the first bid price. Lastly, we determined the variables that influenced households' WTP for CBE development amongst households that participated in the study. Findings from the study established a strong association between households' support for CBE implementation and WTP the first bid price $(25,40,60,100)$ offered to the households in the DBCV questionnaire implemented in the study. The null hypothesis that households' support for the implementation of the CBE development is independent of the first bid price is strongly rejected. This result established that households that support the development of $\mathrm{CBE}$ project will probably pay the first bid price when asked to do so.

The estimate of the WTP from the bivariate probit model shows that households are willing to pay between R121 and R125 every month for a period of 3 years to support the establishment of the CBE project in their communities, thus confirming the findings of Ezebilo et al. (2010) and Kimengsi et al. (2019) that the community will contribute or pay for the ecotourism project if they stand to benefit from the project.

In conclusion, this study established that households in communities adjacent to the AENP are in support of the establishment of CBE project as long as it will benefit their communities in general and individuals in particular. This support is demonstrated by households' willingness to contribute money for the implementation of a communitybased project in their communities. Based on this finding, the study concluded that the implementation of CBE project that offers craft-making market, village accommodation and village tour can showcase adjacent communities to visitors and thus assist the park management to strengthen the existing relationship between the park and the communities.

\section{Acknowledgements}

The authors thank the managements of the South African National Parks (SANParks) and the Addo Elephant National Park for the provision of accommodation and survey logistics during the tourists' survey in 2016 and for assisting with the recruitment of enumerators for the household survey. The authors convey their special thanks to Marna Herbst for the 
invaluable contribution to the tourists' questionnaire guide and for facilitating authors' contractual agreement with SANParks.

\section{Competing interests}

The authors have declared that no competing interest exists.

\section{Authors' contributions}

B.E.A. designed this study under the supervision of A.M. The study survey, data analysis and the writing of the first draft of the manuscript were performed by B.E.A. A.M. improved substantially on the subsequent drafts that culminated in the final draft submitted to Koedoe.

\section{Funding information}

This study was self-funded.

\section{Data availability statement}

Data sharing is not applicable to this article as no new data were created or analysed in this study.

\section{Disclaimer}

All the views and opinions expressed in this article are that of the authors and do not represent that of the University of Fort Hare, the South African National Parks and the Addo Elephant National Park. The authors are responsible for errors and omissions in the submitted content, if any.

\section{References}

Addo Elephant National Park, 2015, Park management plan, South African National Parks, Pretoria.

Akinyemi, B.E. \& Mushunje, A., 2017, 'Willingness to pay for Wild Coast nature reserves conservation through community-based ecotourism projects', International Journal of Applied Business and Economic Research 15(16), 57-73.

Alberini, A., 1995, 'Optimal designs for discrete choice contingent valuation surveys: Singlebound, double-bound, and bivariate models', Journal of Environmental Economics and Management 28(3), 287-306. https://doi.org/10.1006/jeem.1995.1019

Algotsson, E., 2006, 'Wildlife conservation through households-centred approaches to natural resource management programmes and the control of wildlife exploitation" Local Environment 11(1), 79-93. https://doi.org/10.1080/13549830500396230

Arrow, K., Solow, R., Portney, P., Leamer, E., Radner, R. \& Schuman, H., 1993, 'Report of the NOAA panel on contingent valuation', Federal Register 58(10), 4601-4614.

Aswani, S. \& Weiant, P., 2004, 'Scientific evaluation in women's participatory management: Monitoring marine invertebrate refugia in the Solomon Islands', Human Organization 63(3), 301-319. https://doi.org/10.17730/humo.63.3.r7kgd4thktmyf7k1

Balint, P.J., 2007, 'A proposed general model for Southern African community-based wildlife management', Human Dimensions of Wildlife 12(3), 169-179. https://doi. org/10.1080/10871200701322829

Banzhaf, S., Dallas, B., Evans, D. \& Krupnick, A., 2004, Valuation of natural resource improvements in the Adronacks, Resource for the Future, Washington, DC.

Biadgilign, S., Reda, A.A. \& Kedir, H., 2015, Determinants of willingness to pay for the retreatment of insecticide treated mosquito nets in rural area of eastern Ethiopia' International Journal for Equity in Health 14, a99. https://doi.org/10.1186/ s12939-015-0249-9

Bonan, J., Lemay-Boucher, P. \& Tenikue, M., 2013, 'Households's willingness to pay for health microinsurance and its impact on actual take-up results from a field experiment in Senegal', The Journal of Development Studies 50(10), 1445-1462. https://doi.org/10.1080/00220388.2014.940909

Buckley, R., 2001, 'Major issues in tourism ecolabelling', in X. Font \& R.C. Buckley (eds.), Tourism ecolabelling: Certification and promotion of sustainable management, pp. 19-26, Cabi, New York, NY

Cameron, T. \& James, M.D., 1987, 'Efficient estimation methods for "close-ended" contingent valuation surveys', The Review of Economics and Statistics 69(2), 269276. https://doi.org/10.2307/1927234
Cameron, T. \& Quiggin, J., 1994, 'Estimation using contingent valuation data from a "dichotomous choice with follow-up" questionnaire', Journal of Environmental
Economics and Management 27(3), 218-234. https://doi.org/10.1006/ Economics and

Carson, R.T., 2000, 'Contingent valuation: A user guide', Environmental Science and Technology 34(8), 1413-1418. https://doi.org/10.1021/es990728j

Ceballos-Lascurain, H., 1987, Tourism, ecotourism and protected areas, Internationa Union for Conservation of Nature (IUCN) (World Conservation Union), Gland.

De Witt, L., Van der Merwe, P. \& Saayman, M., 2011, 'An ecotourism model for South African National Parks', in Book of proceedings, vol. II: International conference on tourism and management studies, University of the Algarve, Algarve, 26-29 October 2011.

Du Preez, M., Tessendorf, S. \& Hosking, S., 2010, 'Application of the contingent valuation method to estimate the willingness to pay for restoring indigenous vegetation in Underberg, KwaZulu-Natal, South Africa', South African Journal of Economic and Management Sciences 13(2), 135-157. https://doi.org/10.4102/sajems.v13i2.42

Ezebilo, E.E., Mattsson, L. \& Afolami, C.A., 2010, 'Economic value of ecotourism to local communities in the Nigerian rainforest zone', Journal of Sustainable Development 3(1), 51-60. https://doi.org/10.5539/jsd.v3n1p51

Fabricius, C., Koch, E. \& Magome, H., 2001, Community wildlife management in Southern Africa: Challenging the assumptions of Eden, Russell Press, Nottingham. Fennel, D.A., 2002, Ecotourism programme planning, Cabi, New York, NY.

Ferreira, O., 1980, Memoirs of General Ben Bouwer, Human Sciences Research Counci (HSRC), Pretoria.

Greene, W.H., 2018, Econometric analysis, 8th edn., Pearson, New York, NY.

Haab, T.C. \& McConnell, K.E., 2002, 'Referendum models and economic values: Theoretical, intuitive, and practical bounds on willingness to pay', Land Economics 74(1998), 216-229. https://doi.org/10.2307/3147052

Hadker, N., Sharma, S., David, A. \& Muraleedharan, T., 1997, 'Willingness to pay for Borivli National Park: Evidence from a contingent valuation', Ecological Economics 21(2), 105-122.

Heechan, K., 2006, 'Essays on methodologies in contingent valuation and the sustainable management of common pool resources', PhD dissertation, The Ohio State University, Columbus, $\mathrm{OH}$.

Herriges, J.A. \& Shogren, J.F., 1996, 'Starting point bias in dichotomous choice valuation with follow-up questioning', Journal of Environmental Economics and Management 30(1), January, 112. https://doi.org/10.1006/jeem.1996.0008

Huang, J. \& Smith, V.K., 1998, 'Monte Carlo benchmarks for discrete valuation methods', Land Economics 74(2), 186-202. https://doi.org/10.2307/3147050

Jeanty, W.P., 2006, 'Two essays on environmental and food security', PhD dissertation, Graduate School of Ohio State University, s.l.

Kate, H., 2006, Partnerships to manage conservation areas through tourism: Some best practice models between government, indigenous communities and the private sector in Canada and South Africa, Government of Western Australia, Department of Conservation and Land Management, Perth.

Kimengsi, J.N., Kechia, M.A., Azibo, B.R., Pretzsch, J. \& Kwei, J., 2019, 'Households' assets dynamics and ecotourism choies in the Western Highlands of Cameroon', assets dynamics and ecotourism choies in the Western Highlands
Sustainability 11(7), 1844. https://doi.org/10.3390/su11071844

Krinsky, I. \& Robb, A.L., 1986, 'On approximating the statistical properties of elasticities', The Review Economics and Statistics 68(4), 715-719. https://doi. org/10.2307/1924536

List, J.A. \& Gallet, C., 2001, 'What experimental protocol influence disparities between actual and hypothetical stated values?', Environmental and Resource Economics 20, 241-254. https://doi.org/10.1023/A:1012791822804

Loureiro, M., Gracia, A. \& Nayga, R.M., 2006, 'Do consumers value nutritional labels?', European Journal of Agricultural Economics 33(2), 249-268. https://doi. org/10.1093/erae/jbl005

Marine Le, G., 2009, 'Definition, measurement and determinants of the consumer's willingness to pay: A critical synthesis and directions for further research', Recherche et Applications en Marketing 24(2), 91-113. https://doi. org/10.1177/205157070902400205

Mitchell, R. \& Carson, R., 1989, Using surveys to value public goods. The contingent valuation method, Resources for the future, Washington, DC.

Park, T., Loomis, J. \& Creel, M., 1991, 'Confidence intervals for evaluating benefits from dichotomous choice contingent valuation studies', Land Economics 67(1), 64-73. https://doi.org/10.2307/3146486

Paterson, A.R., 2007, 'Wandering about South Africa's new protected areas regime', South African Public Laws Journal 22, 1-3.

Pelser, A., Redelinghuys, N. \& Velelo, N., 2013, 'Protected areas as vehicles in population development: Lessons from rural South Africa', Environment, population development: Lessons from rural South Africa', Environment,
Development and Sustainability 15(1), 1205-1226. https://doi.org/10.1007/ s10668-013-9434-4

Powell, R.B. \& Ham, S.H., 2008, 'Can ecotourism interpretation really lead to pro-conservation knowledge, attitudes and behaviour? Evidence from the Galapagos Islands', Journal of Sustainable Tourism 16(4), 467-489. https://doi. org/10.1080/09669580802154223

Reitz, D., 1929, Commando, Faber \& Faber, London.

South Africa Nature Reserves \& National Parks, 2016, March 08, The bloody history of Addo Elephant National Park, Siyabonga Africa, viewed 08 March 2019, from https://www.nature-reserve.co.za/history-addo-elephant-natio.

South African National Parks (SANParks), 2005, 'Addo Elephant National Park official guide', the tourism blueprint, South African National Parks, Pretoria. 
South African National Parks (SANParks), 2011, People and conservation: A brief history, viewed 08 March 2019, from http://www.sanparks.org/people/about/history.php.

Statistics South Africa, 2014, General household survey, Statistical release P0318 Statistics South Africa, Pretoria.

The International Ecotourism Society (TIES), 2015, What is Ecotourism?, The International Ecotourism Society, Washington, DC, viewed 25 January 2019, from http://www.ecotourism.org/what-is-ecotourism.
Timmermans, H. \& Naicker, K., 2002, 'The land', in R. Palmer, H. Timmermans \& D. Fay (eds.), From conflict to negotiation: Natural-based development on South Africa's Wild Coast, Chap. 1, pp. 2-14, Human Science Research Council, Pretoria.

Vlok, J.H., Euston-Brown, D. \& Cowling, R., 2003, 'Acocks' Valley Bushveld 50 years on: New perspective on the delimitation, characterisation and origin of the thicket vegetation', South African Journal of Botany 69(1), 27-51. https://doi. org/10.1016/S0254-6299(15)30358-6 